\title{
POLITITIKK

\section{Xi og Kina på terskelen til en ny tid}

Bjørnar Sverdrup Thygeson

Norsk utenrikspolitisk institutt (NUPI)

\section{Den kinesiska drömmen: Xi, makten och utmaningarna}

Börje Ljunggren

Stockholm: Hjalmarson \& Högberg 2017

\section{Det perfekte diktatur: Kina i dag}

Stein Ringen

Oslo: Scandinavian Academic Press 2017

China in the Era of Xi Jinping: Domestic and Foreign Policy Challenges

Robert S. Ross og Jo Inge Bekkevold (red.)

Washington D.C.: Georgetown University Press 2016

\section{Strategic Adjustment and the Rise of China}

Robert S. Ross og Øystein Tunsjø (red.)

Ithaca: Cornell University Press 2017

\section{Innledning}

Etter fem år med Xi Jinping ved roret for den spirende supermakten Kina, ser verden allerede annerledes ut. Beijing har i økende grad beveget seg mot begivenhetenes sentrum i en tid hvor globale institusjoner har blitt svekket av krefter fra mange sider, og den allerede pågående maktforskyvningen østover har blitt påskyndet av Trump-administrasjonens isolasjonistiske slagside. Når det nå igjen er duket for den årlige folkekongressen $\mathrm{i}$ et vårlig Beijing, etter at det kinesiske kommunistpartiets (KKP) femårige nasjonale partikongress i oktober sementerte Xi Jinpings maktposisjon ytterligere, skjer dette dermed i en brytningstid for Kinas rolle utenlands og

\footnotetext{
^Kontaktinformasjon: Bjørnar Sverdrup Thygeson, bst@nupi.no

(C2018 Bjørnar Sverdrup Thygeson. This is an Open Access article distributed under the terms of the Creative Commons Attribution 4.0 International License (http://creativecommons.org/licenses/by/4.0/), allowing third parties to copy and redistribute the material in any medium or format and to remix, transform, and build upon the material for any purpose, even commercially, provided the original work is properly cited and states its license. Citation: Bjørnar Sverdrup Thygeson (2018). Xi og Kina på terskelen til en ny tid, 76:183-192. http://dx.doi.org/10.23865/ intpol.v76.1042
} 
landets politiske system innenlands. Xi Jinping har lykkes med å stødig konsentrere mer makt i sine egne hender, en prosess som nylig nådde et crescendo i forslaget om å fjerne et av de viktigste arvestykkene fra Deng Xiaopings bestrebelser på å forhindre kinesisk ettmannsvelde, nemlig den eksisterende tiårsgrensen for hvor lenge Kinas toppleder kan bekle sitt verv. Når så både Kinas og verdens politiske strukturer er i rask og grunnleggende endring, mens mer politisk og økonomisk makt forskyves til Kina, og makten i Kina i økende grad konsentreres hos Xi Jinping, er kunnskap om de sosiale, økonomiske og politiske prosessene innad i Kina vitalt viktige.

I en slik betydningsfull periode for Kina er det dermed særdeles betimelig at fire nordiske forfattere har bidratt med nyutkomne bøker som analyserer og belyser de viktigste trendene i den påbegynte Xi-æraen. Disse verkene skiller seg noe ad, fra Stein Ringens politiske taksonomi av ettpartistaten Kina, til Börje Lundgrens encyklopediske ettbindsverk, og de to redigerte bokutgivelsene av henholdsvis Ross \& Bekkevold og Ross \& Tunsjø, som begge skilter med et mangfold av ledende bidragsytere. Til felles har dog disse bøkene at hovedfokuset er på Kinas interne utfordringer, det nye lederskapets rolle under $\mathrm{Xi}$, og hvordan disse interne politiske prosessene kan gi seg utslag internasjonalt. De er med andre ord gode bøker til rett tid, og er verdt å motta oppmerksomhet fra så vel Kina-forskere som den jevne samfunnsborger.

\section{Et diktaturs taksonomi}

Sosiolog og emeritus-professor ved Oxford, Stein Ringen, sin bok om det kinesiske politiske systemet: Det perfekte diktatur, er nylig lansert i sin norske oversettelse. Etter en merittert rekke bøker om demokrati og velferdsspørsmål er dette første gang Ringen har begått en bok om Kina. Dog, som han selv påpeker, er boken resultatet av at Kina i de senere årene har gjort seg selv til et uunngåelig tema for den som er generelt interessert i politiske systemer. Ringen erklærer ærlig at han skriver en utenforstående sin bok om Kina, men argumenterer for at nettopp dette er en styrke (s. 76). Dette argumentet underbygges ved at Ringen med bred pensel skildrer et sinologisk fagmiljø med overdreven respekt for Kina, basert på «en eldgammel vestlig fascinasjon» (s. 79). Mens det åpenbart er lett å si seg enig med Ringen når han påpeker problematikken ved selvsensur, går han dog $i$ overkant langt med å diagnostisere et helt fagmiljø som forblindet av Kina-fascinasjon. I tillegg begrunnes heller ikke påstanden om at det er en større risiko for integriteten å studere Kina, enn det er å studere et hvilket som helst annet land. For de omtalte bøkene her er kritikken definitivt irrelevant, og for det ikke ubetydelige antall Kina-forskere i Norge og utenlands som har blitt nektet innreise til landet av kinesiske myndigheter, Andrew Nathan er ett eksempel fra herværende bokutvalg, klinger anklagene spesielt hult.

Dette underslår dog hverken viktigheten eller riktigheten av hovedambisjonen i Ringens bok, nemlig å underkaste Kina analyser basert på generelle politiske teorier. Spesielt i en situasjon hvor det kinesiske diktaturets fremste ideologiske forsvar 
nettopp er å trekke frem at Kina er et tilfelle sui generis, som ikke lar seg innfatte av politiske og økonomiske tyngdelover formulert i Vesten. Stein Ringen strukturerer dermed boken langs en diskusjon rundt hvorvidt Kina passer inn i en av tre generelle idealtyper, det han definerer som teser for hva det kinesiske statssystemet kan defineres som; "trivialitetshypotesen (staten er til for seg selv), velferdshypotesen (staten er til for folkets beste) og makthypotesen (staten er til for et ideologisk formål)» (s.106).

Hoveddelen av boken er en gjennomgang og testing av disse hypotesene, og i særdeleshet hvorvidt dagens Kina kan sies å ha en førende ideologi, noe som skiller de pragmatiske trivialitetsstatene fra de korsfarende maktstatene. I gjennomgangen av sine hypoteser tilkjennegir Ringen en god oversikt over KKPs gjøren og laden, og gjør den partibyråkratiske jungelen lett tilgjengelig for den jevne leser. Han tar også for seg, på karakteristisk skarpt observert vis, den «diktatur vs. fattigdomsbekjempelse»dikotomien som ofte på for ukritisk vis har fått polarisere debatten, i Norge så vel som utenskjærs. Diskusjonen innebærer to nøkkelspørsmål: Har KKP gjort en god jobb økonomisk (definisjonen på en velferdsstat), og er de overveldende ideologisk drevet (definisjonen på en maktstat)? Stein Ringen forkaster til syvende og sist velferdshypotesen og tar dermed en klar stilling i et av hovedstridsspørsmålene rundt prestasjonene til Kinas politiske system. Der hvor norske politikere av de fleste fargevalører er samstemmig i beundringen av Kinas raske vekst og fattigdomsreduksjon, sier Stein Ringen seg lite imponert. Kontrasten er slående. Det er også vanskelig å unngå å la seg slå av hvordan strukturen på denne debatten ofte koker ned til et spørsmål om sammenligningsgrunnlag. Ringen velger, med bakgrunn i sin ekstensive forskning på landet, å bruke Sør-Korea som målestokk. Sør-Korea har, som Ringen ganske riktig påpeker, utviklet seg langt raskere og bedre, både med hensyn til økonomisk rikdom, samfunnsmessig velferd og politisk frihet, og dette endatil fra et lavere nivå enn hva Kina startet ut fra.

Om man derimot tar som utgangspunkt Asias andre subkontinent i milliardstørrelse, India, ser bildet annerledes ut. I motsetning til Sør-Korea hadde India høyere BNP per innbygger etter krigen, men Kina har de siste tiårene dratt så kraftig ifra at gjennomsnittlig levealder der er rundt 10 år lengre enn i India. Som Ljunggren peker på i sin bok, er det ingen annen økonomi som har vokst i nærheten av så raskt som den kinesiske over de siste decenniene (s. 230). Ringen avfeier dette med at det snarere beviser Indias problemer enn Kinas fortreffelighet, men etterlater dermed leseren med det ubesvarte spørsmålet om at hvis det virkelig er så enkelt å skape rask og vedvarende økonomisk utvikling, hvorfor har det da vist seg så mye vanskeligere for en milliard indere og en milliard afrikanere å få det til, enn det var for en milliard kinesere?

Om spørsmålet om økonomiske prestasjoner avfeies i overkant raskt, har Ringen rett i at spørsmålet om ideologi og nasjonalistisk agitasjon er et av de viktigste å følge med på fremover, i en periode hvor Xi Jinping ser ut til å lene seg desto mer på ideologiske verktøy for å støtte opp om KKPs legitimitet. Dette er en utvikling som ikke bare er brennaktuell for kinesisk utenrikspolitikk, men også for kinesisk utenrikspolitikk. Som det understrekes av en rekke bidragsytere i Ross \& Tunsjø sin 
bok, dog med et interessant unntak fra James Reilly, er Kinas utvikling langs aksen fra nasjonalisme til hypernasjonalisme en av hovedfaktorene også når sikkerhetssituasjonen i Øst-Asia skal bedømmes fremover.

Kinas «snill purk, slem purk»-tilnærming til sosial kontroll er et av hovedomdreiningspunktene i denne delen av boken. Som det sies er Kina i dag «Et kontrollsystem som ikke kontrollerer det som ikke må kontrolleres, og som i stor grad setter sin lit til egenkontroll» (s. 227). Med bakgrunn i denne subtile kontrollen definerer Ringen det slik at autokrati er et for snilt begrep, mens diktatur er for primitivt, og beskriver treffende dagens Kina som et «kontrollokrati» av det svært subtile slaget. Mot slutten av boken ser dog Ringen inn i krystallkulen og ser, allerede før fjorårets partikongress, på muligheten av at Kina utvikler seg fremover som en "pragmatisk triviellstat» som «sannsynlig minus», og som en "fascistoid totalitærstat» som "sannsynlig pluss».

Stein Ringens forsøk på klassifikasjon av den kinesiske politisk-økonomiske kimceren bidrar med en rekke nyttige betraktninger og ikke minst en rekke treffende begreper som Kina-debatten kan trekke noe godt ut av. Boken utgjør også et godt korrektiv for de av Kinas førstereisgutter som ser den slående likheten mellom Shanghais Pudong og New Yorks Manhattan, og litt for lettvint utleder at de økonomiske strukturene som utgjør fundamentet for disse skyskraperne, også er tilnærmelsesvis like. Å fremstille boken som et korrektiv til den eksisterende litteraturen, spesielt siden bøker om Kinas forestående kollaps har fylt bokhyllene siden 90-tallet, er dog å benytte Ringens betydelige akademiske tyngde til å slå inn åpne dører. Stein Ringens akademiske vidsyn og skarpe penn giør likevel dette til et godt utgangspunkt for viktige diskusjoner rundt vår store nesten-nabo i øst.

\section{Store kinesiske leksikon}

Ringens analyse av det kinesiske politiske systemet suppleres av en annen nylig utgitt bok med et langt bredere perspektiv. Det svenske Kina-miljøets doyen, Börje Lundgren, har i sin bok "Den kinesiska drömmen» søkt å destillere sin erfaring fra det svenske diplomatiet, deriblant som ambassadør i Kina og Vietnam, og fra sitt akademiske Asia-engasjement tilknyttet Harvard og Utrikespolitiske institutet i Stockholm. Et raskt endret Kina i en raskt endret verden medførte nødvendigheten av ikke bare en nyutgivelse av hans bok om den kinesiske drømmen fra 2015, men en tydelig revidert videreutvikling av en i utgangspunktet omfattende populærvitenskapelig Kina-klassiker.

Lundgrens bok er en kompakt murstein av kunnskap, som allikevel aldri kneler under vekten av sin encyklopediske tyngde. Språkføringen er lett tilgjengelig og krydret med pusterom i form av anekdoter og betraktninger fra års virke $\mathrm{i}$ «Det fjerne Østen». Encyklopedisk er boken først og fremst i ordets positive betydning, som beskrivelse av den bredden av Kina-kunnskap den dekker: Om man ønsker seg en gjennomgang av Xis liv og familiebakgrunn, finner man det.Vil man vite bakgrunnen for at unge mennesker strømmer til kommunistpartiet som aldri før, er dette også 
pedagogisk og lettfattelig forklart. Det samme gjelder om man skulle lure på den religiøse og spirituelle oppblomstringen man ser i dagens Kina, detaljer rundt Kinas lange liste av miljøproblemer, eller bakgrunnen for den kinesiske overproduksjonen av stål, som ble et av Trumps vinnende ankepunkter under presidentvalgkampen. Forordet «Ödesmettet drama» åpner med å erklære at en verden i rask endring er knapt til å kjenne igjen: USAs president river i stykker internasjonale handelsavtaler, og Kinas kommunistparti erklærer seg som frihandelens beskytter i Davos. Dette samtidig som Xi Jinping søker å benytte alle tilgjengelige maktmidler for at KKP skal nå sine selverklærte hundreårsmål om vekst og velstand, uten å ende opp som en ny Gorbatsjov, et navn som i disse kretser kun er negativt ment.

Lundgren definerer tidlig hva han anser som den fundamentale motsetningen (for å benytte kommunistpartiets eget teoretiske begrepsapparat) i det kinesiske samfunnet av i dag; nemlig den som befinner seg mellom en stadig mer ensrettet ettpartistat, som søker å styre et stadig mer pluralistisk samfunn. For mens Kinas styresmakter med digitalteknologiens hjelp bygger et gigantisk propaganda- og kontrollsystem, etter at de slo ned demonstrasjonene på Den himmelske freds plass i 1989, finnes det på tross av dette «ett vitalt embryo till civilsamhälle, rikt på debatt, organisationer, entreprenörskap, innovationer och protester. I dess vitalitet ligger nyckeln till landets långsiktiga pånyttfödelse»(s. 19). En av de tingene som skiller Lundgrens politiske analyse fra Ringens, er dermed Lundgrens tro på det dynamiske kinesiske sivilsamfunnets potensial, selv når det er under press. Den tilstrammingen som har pågått under Xi Jinpings fem første år, ligger dog per nå an til å fortsette, noe som vil sette et både tøffere og mer sofistikert innrettet press på sivilsamfunnet og dets evne til å skape nasjonal fornyelse enn hva man har sett de siste tiårene.

Boken starter med en historisk bakgrunn og en del som trekker de lange linjene i kinesisk politisk historie. Mot en bakgrunn av disse lange linjene går Lundgren i detalj inn på de raske endringer både Kina og verden har stått overfor de siste årene. Som et eksempel trekker han frem hvordan han som svensk UDs Asiaansvarlige var med på utenriksminister Anna Lunds møte med Dalai Lama i år 2000, og de etterfølgende kinesiske protestene. Nå, kun 17 år senere, påpeker han med referanse til Norges situasjon etter 2010 hvordan politisk karantene antagelig ville ha erstattet formelle protester som reaksjon. Av de utviklingstrekk Lundgren advarer spesielt mot, er stegene i retning av en informasjonsteknologisk basert autoritærstat, hvis kontrollpotensial kan mangedobles ved å utnytte det moderne menneskets kontante digitale tilstedeværelse. Han advarer også mot å se for ukritisk på at et stadig mer innovativt Kina vil kjøre seg fast i «mellominntektsfellen». Men, som han ganske riktig peker på, er det flere ting som tyder på at Kina beveger seg $\mathrm{i}$ en retning av avinstitusjonalisering, bort fra det korpus av regler som CCP hadde lykkes i å etablere etter Mao, en utvikling som ikke i noe land frem til nå har vært godt nytt for økonomien. Xis ambisjoner om å avskaffe åremålet for presidentvervet føyer seg inn i denne trenden, som både Ringen og Ljunggren samstemmer i at har funnet sted. 
Gjennom bokens avsluttende kapitler om Kinas utenrikspolitiske relasjoner presenteres på et veloverveid og lettfattelig vis det skjebnetunge "G2»-forholdet mellom USA og Kina. Av spesiell stor nytte for tilskuere i den offentlige debatten er også Lundgrens presentasjoner av komplekse, men viktige samtidige temaer som stridighetene i Sør- og Øst-Kinahavet, og de bredere ringvirkninger av Kinas styrkede maktposisjon for både opprettholdelsen av den videre "Øst Asiatiske freden» og for fremtidsutsiktene for internasjonale institusjoners styringsdyktighet. Som han påpeker har Kinas vekst de siste årene skjedd $\mathrm{i}$ en verden hvor det internasjonale systemet generelt har opplevd en svekkelse heller enn å bli styrket. For Lundgren er ikke Kina et perfekt diktatur, men snarere et kontrollregime som kjemper med det grunnleggende dilemmaet at "samhället har sin egen rörelsesenergi, och en annan destination än partistaten» (s. 93). I sine spekulasjoner om fremtiden foretrekker han den gylne middelvei. Kina vil ifølge Lundgren ikke bli noen dominerende supermakt av USA-støpning, men heller ikke et nytt Japan, hvor 70-tallets spådommer om stormaktsstatus endte opp som en historisk parentes. Grunngivelsen for denne konklusjonen kunne ha vært bygget noe mer ut, men Lundgren har i alle tilfelle rett $i$ at verden står overfor en epokegjørende internasjonal maktforskyvning som maner Thukydids stormaktsdilemmaer frem igjen fra noen av historiens blodigste skygger. Hvordan dette håndteres, i spenningsfeltet mellom et stigende Kina og et USA presset på defensiven i Stillehavet, er som Lundgren sier et av de mest avgjørende globale spørsmålene å følge med på de neste tiårene, og han legger en solid kunnskapsbunn til rette for lesere som ønsker å tilegne seg mer utdypende kunnskap, noe man for eksempel kan finne i overflod i Ross \& Tunsjøs teoritunge og utdypende redigerte bokverk om emnet.

I sum har Lundgren lykkes med å syntetisere et langt og lærd liv med tett Kina-kontakt til et overflødighetshorn av en bok med åpenbar nytteverdi for enhver borger som ønsker å lære seg mer om landet og dets rolle i verden. Boken er heller aldri plagsomt Sverige-sentrert, og det er ingen grunn til at denne boken ikke skulle bli omfavnet av lesende og tenkende sirkler i hele Skandinavia. Gjennom bokens 600 sider serveres leseren et overmåte bredt kunnskapsspekter, formulert med en statsmanns forklaringsevne, formet av tiår med fingeren tett på Kinas og Asias politiske puls. I tillegg har Lundgren valgt bort fotnoter til fordel for direkte bokpresentasjoner i teksten, noe som fungerer svært godt for denne typen populærvitenskapelig bok. Fordelen dette gir leseren, er at boken inneholder godt oppsummerte litteraturpresentasjoner gjennom 600 sider, som i tillegg til forfatterens egne betraktninger utgiør et veritabelt ettbinds Kina-bibliotek.

\section{Eksperter i dybden}

I samarbeid med Robert S. Ross fra Boston College og Harvard University redigerte Jo Inge Bekkevold i 2016 antologien "China in the Era of Xi Jinping", som presenterer et overblikk over de sentrale feltene av kinesisk innenriks- og utenrikspolitikk. 
Bekkevold har, som leder for Senter for asiatiske sikkerhetsstudier ved IFS og med mangeårig erfaring fra det norske diplomatiet, sammen med Ross lyktes i å få på plass noe av et internasjonalt stjernelag. Denne suksessen ble nylig fulgt opp videre av samme institutt, da professor ved IFS, Øystein Tunsjø, i nytt samarbeid med Robert S. Ross redigerte boken «Strategic Adjustment and the Rise of China», utgitt på tampen av 2017.

Disse to bokverkene står i et tematisk sammenflettet yin-yang-forhold i spennet mellom innenriks- og utenrikspolitikk. Ross \& Bekkevolds bok har som sitt hovedtema innenrikspolitiske dynamikker i Kina, men demonstrerer også tydelig hvordan disse har konsekvenser for landets utenrikspolitikk. Ross \& Tunsjø på sin side har utenrikspolitiske prosesser og geopolitisk maktforskyvning i Øst-Asia generelt som sitt fokus. Sistnevnte bok er dog bevisst på sammenhengen mellom utenriksog innenrikspolitiske prosesser, og inkluderer kapitler om kinesisk nasjonalisme og økonomi, som gjør boken relevant også for dette bokessayet. Begge bøkene med utspring fra IFS har til felles at de lar noen av verdens fremste Kina-kjennere ta for seg sine spesialfelt, for slik å belyse sentrale dimensjoner av Kinas innenriks- og utenrikspolitiske trender og utfordringer under Xi Jinpings lederskap.

Ross \& Bekkevolds bok er delt inn i én seksjon med kapitler som tar for seg innenrikspolitiske temaer, og én med forfattere som fokuserer på utenrikspolitiske aspekter ved dagens Kina. Gjennom disse kapitlene tar et merittert knippe akademikere fra USA, Singapore, Norge og andre land opp en rekke kjerneaspekter som preger og kjennetegner Xis første år ved makten. Boken beveger seg dermed fra temaer som kjennetegn ved Kinas nye ledergenerasjon og analyser av hvilke interne institusjoner og rammeverk de må bevege seg innen, til betraktninger om Kinas rolle i verdenshandelen og internasjonale organisasjoner. Med et gjennomgående høyt nivå på kapitlene besørger bokens 14 bidragsytere, på en overbevisende måte, dyptpløyende og oppdatert forskning på et nivå som kanskje kan bli i overkant detaljert for den jevne leser, men som er desto mer interessant for enhver Kina-student.

Gjennom mosaikken av forfatterbidrag tegnes et dekkende bilde av nøkkelaktører og strukturer i et Kina på terskelen til en avgjørende tid. Som Bekkevold og Ross ganske riktig påpeker i sin introduksjon, har Kinas raske vekst også ført med seg en opphopning av utfordringer både utenriks og innenriks, som gjør de neste ti årene avgjørende for folkerepublikken. Som de formulerer det: «Kina trenger vist og modent lederskap som aldri før» (s. xiii). Er så Xi Jinping og topp-politikerne i hans skygge de rette for dette? Dette spørsmålet ligger som bakteppe for de fleste av bokens bidragsytere, om de enn går i detalj på implikasjoner av aldersgrensene i KKPs generasjonssystem, ser nærmere på interesser og kapabiliteter hos de ulike bidragsyterne i utformingen av kinesisk utenrikspolitikk, eller går strukturelle svakheter i Kinas økonomi nærmere etter i sømmene.

Viktigheten av en grundig fundert økonomiforståelse for å kunne analysere et regime som det kinesiske kan knapt overvurderes, og hvis bøker av politiske teoretikere, som Ringens herværende bidrag, har en tendens til å fare med harelabb over 
økonomiske dynamikker, finner man i denne boken bunnsolide bidrag. Et av de mange nøkkelpunkt boken bidrar med å belyse, er at Kina etter hvert som de økonomiske særinteressene har bygget seg opp på ryggen av tidligere og enklere reformer, giør det vanskeligere å gjennomføre nye reformer, selv når «alle», inkludert selve propagandaapparatet, erkjenner at dette er avgjørende viktig. Denne «kredibilitetskrisen» ville sette en hvilken som helst politiker på en hard prøve. Det konkluderes i Barry Naughtons kapittel: «Selv om Xi Jinping aksepterer at reformer er nødvendige, er han mer personlig engasjert i prosjektet om å giøre Kina til en mektig nasjon og seg selv til en mektig leder» (s. 86-87). I tiden etter den 19. partikongressen er dette en av mange aspekter det er viktig å ta hensyn til, når signalene fra et nytt lag av toppledere med Xi som overhode skal fortolkes.

Det samme gjelder spørsmål om Kinas indre politiske stabilitet, og hvordan det nye lederskapet best skal håndtere de mellom 100 og 200000 protestaksjonene som finner sted årlig i Kina. Joseph Fewsmith, for eksempel, argumenterer i sitt kapittel for at det kinesiske lederskapet $\mathrm{i} ø$ kende grad har begynt å beskrive Kina som nettopp et sui generis-tilfelle, som ikke kan måles etter vestlige modeller for politisk soliditet. Dog, i likhet med både Ringen og de andre bidragsytere i herværende bøker, stiller han seg skeptisk til om Kina virkelig er «spesiell» nok til å kunne utfordre økonomiske og politiske tyngdelover uten store vanskeligheter i tiden fremover.

Ross \& Bekkevolds bok dekker i det hele de fleste relevante aspekter svært grundig, og mer til. Det er selvfølgelig vanskelig å rekke over et veldig vidstrakt utvalg temaer $\mathrm{i}$ en slik dybde som denne boken klarer, men en noe påfallende unnlatelse er det nå at det ikke finnes noe eget kapittel som også tar for seg de enorme utfordringene Xi Jinping og hans kabinett står overfor innen klima og miljø, et område som også påvirker en rekke andre arenaer, fra sosial stabilitet til økonomi og internasjonalt samarbeid. Alt i alt lykkes dog boken i å gi et fremragende overblikk over det kinesiske rikets tilstand $i$ en viktig tid for Kina og verden, og lever i så måte fullt opp til sin egen tittel. Som redaktørene i bokens avslutning påpeker har maktkonsentrasjonen under $\mathrm{Xi}$ Jinping langt fra eliminert spenningspunktene og dilemmaene $\mathrm{i}$ kinesisk innenriks- og utenrikspolitikk (s. 277).

I Ross \& Tunsjøs nylige utgivelse er strukturen tilsvarende satt opp, og 10 bidragsytere med høy profil fra både hjemland og utland har fått godt armslag til å gi sine bidrag tilknyttet det essensielle temaet, som er kinesisk utenrikspolitikk i konteksten av denne fremvoksende supermaktens "nære utland", hvor den stigende stormakten Kina i økende grad butter mot de etablerte maktstrukturene som den etablerte supermakten USA har bygget opp. Bokens hovedfokus er hvordan denne geostrategiske dørstokkmilas dynamikker spiller seg ut på det regionale plan, hvor statene i Øst-Asia, hver på sitt vis, søker å tilpasse seg den radikalt endrede maktstrukturen, en prosess som Tunsjø spesielt underkaster grundig, og kjærkomment systematisk, analyse i sine kapitler (hhv. s. 41 og 285).

Boken er delt inn i tre hoveddeler; i den første delen drøftes de bredere strukturene i den østasiatiske maktforskyvningen, med bidrag som også har betydelig 
teoretisk interesse. I bokens andre del fokuserer kapitlene på hvordan Japan og Sør-Korea håndterer Kinas økende maktposisjon, mens den siste delen tilegnes forholdet mellom Kina og USA. Sitt utenrikspolitiske fokus til tross, har flere av kapitlene også relevans for dette bokessayets fokus på innenrikspolitiske trender i Kina. Som Ross og Tunsjø understreker er det en sentral læresetning innen den neoklassiske realistiske tankeskolen bidragsyterne befinner seg $i$, at endringer $i$ den internasjonale maktbalansen samvirker med innenrikspolitiske drivkrefter som politisk lederskap og nasjonalistisk agendasetting i å forme regionens utenrikspolitikk (s. 4). Som sådan er for eksempel Schwellers diskusjon om nasjonalismens betydning for utenrikspolitikken interessant. I forlengelsen av den betydning Stein Ringen tillegger potensialet for at en ny ideologi kan spire frem fra kinesisk nasjonalisme, er Scwellers advarsel om at den innenrikskinesiske politiske dynamikken kan gi seg utslag i økende nasjonalisme både om landet opplever fortsatt økonomisk vekst, men også om landet skulle oppleve en økonomisk nedtur, svært betimelig. James Reilly analyserer på sin side nasjonalistiske og økonomiske drivkrefter i Kinas Japan-politikk fra 2002 til 2010, og argumenterer for at begge disse drivkrefter er underordnet strukturelle kinesiske sikkerhetsimperativer. Om de bredere utviklingstrekk i regionen samsvarer med en så enkel dynamikk, er et åpent spørsmål, men spenningene mellom økonomiske, ideasjonale og sikkerhetspolitiske drivkrefter vil ikke forsvinne hverken i Kinas innenrikspolitikk eller i regionens utenrikspolitikk i den nærmeste årene.

Daniel W. Drezners interessante analyse av grunnene til at Kina i etterkant av den økonomiske krisen i 2008 valgte å bruke sin finansielle tyngde, ikke til å forsøke å knekke det eksisterende økonomiske systemet, men til å bevare det, griper inn i den bredere debatten om Thykedides-fellen, som bl.a. også Ljunggren har viet mye plass. Drezners analyse finner at kineserne i tiden etter finanskrisen så seg selv tjent med det bestående, og nettopp ikke anså seg selv som sui generis til en slik grad at de ville være tjent med å fremme en alternativ modell. "Kinas interne uenighet over sin egen økonomiske modells fremtid giør det umulig for kinesiske tjenestemenn å artikulere et koherent alternativ til the Washington Consensus» (s. 90). Dette kapittelet understreker dermed hvorfor det er ekstra god grunn til å følge med når $\mathrm{Xi}$ Jinping på den 19. partikongressen i høst avvek fra tidligere kinesisk konsensus, og snakket nettopp om det kinesiske økonomiske systemet som et potensielt konkurrerende alternativ for andre land å følge. Det er dog interessant å merke seg at en slik retorisk erklæring kommer samtidig som store innenrikspolitiske utfordringer og ubalanser i praksis på langt nær er ryddet opp i, slik både Drezner og andre bidragsytere her nevnt peker på. I det hele går bokens kapitler på grundig og givende vis igjennom en rekke av de utfordringer og selvmotsigelser som ligger an til å prege Øst-Asia i tiden fremover. Boken er derfor et kjærkomment tilskudd til en dypere forståelse av det kinesiske fenomenet og ringvirkningene Kinas utvikling og politiske retning har for både dets egne innbyggere, dets naboer, og i siste instans også oss. 


\section{Konklusjon}

Det har i det hele vært et godt år for den skandinaviskspråklige Kina-litteraturen, og spesielt har de foreliggende bøkene med fokus på kinesisk innenrikspolitikk bidratt fruktbart med høy faglig kvalitet i en viktig tid. Om temaet i disse fire verkene i stor grad er overlappende, er dog bøkene allikevel av en overraskende komplementær art: Er man et gjennomsnittlig engasjert samfunnsmenneske som ønsker å utvide sin allmenndannelse om Kina, utgiør Börje Lundgrens bok en særdeles grundig og bred Kina-introduksjon, som vil gjøre deg i stand til å briljere i selskapslivet på nær hvert et Kina-relatert emne samtalen skulle komme inn på. For videre fordypning i emnet er Ross \& Bekkevold og Ross \& Tunsjø sine bøker neste steg. Der formidler en rekke verdensledende forskere cutting-edge kunnskap på et noe smalere, men allikevel svært omfattende utvalg av emner, i den førstnevnte boken med hovedfokus på det innenrikspolitiske spekteret, og den sistnevnte med utenrikspolitisk orientert overvekt. Med denne bakgrunnen er så Stein Ringens bok utelukkende viet Kinas interne politiske system med et blikk utenfra, og vil være viktig lesning for enhver som ønsker å begi seg inn i debatten på dette feltet. Kina har aldri vært viktigere for de nordiske landene enn i dag, og viktigheten av å forstå landet er desto større. Heldigvis bidrar disse bøkene til at det å tilegne seg grundig kunnskap om Kina, selv på skandinaviske språk, er lettere enn noen gang før.

\section{Om forfatteren}

Bjørnar Sverdrup-Thygeson er forsker ved Norsk Utenrikspolitisk Institutt (NUPI), med kinesisk politikk og internasjonale relasjoner som sitt fagfelt. Han avlegger sin $\mathrm{PhD}$ ved London School of Economics, etter studier i Oxford, Oslo og Kina, og har publisert flere artikler om kinesisk utenrikspolitikk. 